\title{
O SABER SE ENCENA NAS ESCRITAS DE SI? UM PERCURSO DE LEITURA DE TEXTOS DE EDWARD SAID
}

Mayumi Aibe é doutoranda em Literatura, Cultura e Contemporaneidade pela PUC-Rio.

E-mail: mayaibe@gmail.com

\section{Resumo}

Este artigo desenvolve reflexões sobre a ideia de "Oriente", a partir de textos de cunho autobiográfico do intelectual palestino e norteamericano Edward Said. Assim, este trabalho trata da encenação de um personagem "oriental" e "fora de lugar" em seus ensaios e narrativas.

\begin{abstract}
The idea of "Orient" is discussed in this article using texts with autobiographical elements written by the Palestinian-American intellectual Edward Said. Therefore, this work deals with the enactment of an "oriental" and "out of place" character in his essays and narratives.
\end{abstract}

\begin{abstract}
Muitos dos lugares e das pessoas que aqui relembro não existem mais, embora eu me espante frequentemente com o tanto que carrego deles dentro de mim.

Edward Said, Fora do lugar
\end{abstract}

\section{1) Muro, muralha, murada ${ }^{1}$}

Muro, Muralha. Essas são metáforas empregadas por Silviano Santiago no artigo "O começo do fim" (2008), ao falar da tradição estabelecida em 80 anos de leitura da antropofagia de Oswald de Andrade, objeto fundamental de qualquer estudo crítico - ou mesmo de qualquer comentário - sobre o movimento modernista brasileiro e seus desdobramentos. Estas ideias de Santigo contribuem para uma reflexão sobre conceitos cuja interpretação estabelecida já nos direciona a determinados campos de problemas:

Sucessivas gerações de artistas, críticos e pesquisadores brasileiros e estrangeiros sobrepuseram uma formidável tradição hermenêutica ao conceito-chave da vanguarda brasileira dos anos 1920. Ano após ano, década após década, essa tradição se transformou numa muralha. (Santiago, 2008, p. 14).

A proposta de Santiago (2008, p. 14) de repensar a "muralha antropofágica" se abre a um diálogo com o trabalho Beginning of the end: Past, present and future, da artista japonesa Mariko Mori, o qual reúne fotografias de paisagens de $360^{\circ}$ de onze cidades, tiradas entre 1995 e 2000. Conforme sugere o ensaísta brasileiro, citando a Encyclopédie Encarta, as onze cidades representam o passado (Ankgor, Teotihuacán, La Paz e Gizé), o presente (Times Square, em Nova York; Shibuya, em Tóquio; Piccadilly Circus, em Londres; e Hong Kong) e o futuro (o bairro da Défense, em Paris; Xangai; Docklands, em Londres; Odaiba, em Tóquio; e Berlim). Em todas as imagens da série, Mariko aparece deitada dentro de cápsula de plástico transparente, vestindo uma malha futurista - e com certo ar de serenidade encenada.

Além da referência feita à artista no título de seu ensaio, Santiago escolheu, como espécie de epígrafe da reflexão, uma fotografia em que Mariko aparece 
encapsulada em frente às pirâmides de Gizé, no Egito - a única das chamadas Sete Maravilhas do Mundo Antigo a permanecer de pé.

Parece-me instigante evocar, por meio do trabalho artístico de Mariko Mori, essa imagem de muralha, sobretudo pela tentativa de fomentar a criação de novos atravessamentos, de possibilidades de passagens pelo muro erguido por uma tradição crítica.

O gesto de explorar a muralha construída após anos de leituras e críticas de um objeto artístico também foi tema de Silviano Santiago em seu conhecido artigo "Eça, autor de Madame Bovary" (2000). Esse texto se refere ao conto "Pierre Menard, Autor do Quixote" (1989), de Jorge Luis Borges, que fala de um projeto praticamente impossível assumido por seu protagonista: escrever páginas que coincidissem, palavra por palavra, com o Dom Quixote de Miguel de Cervantes. Santiago (2000, p. 47) investe nas potencialidades de tal empreitada, disposta a enfrentar "três séculos em que acontecimentos e descobertas ocasionaram rupturas imprevisíveis e definitivas, inclusive a própria ruptura que significou no século XVII o livro Don Quijote". Assim, o Quixote escrito por Pierre Menard serve de estímulo para propostas de Santiago, interessado em uma estratégia política-cultural para repensar a suposta submissão da cultura latino-americana aos movimentos estéticos e artísticos europeus.

No caso das fotografias de Mariko Mori, a viajante japonesa perpassa passado, presente e futuro, buscando maneiras de realizar a fantasia de estar simultaneamente em todas as civilizações. Nessas fotografias encenadas, conforme afirma Santiago (2008, p. 27), "o sujeito está ali e está alhures, num outro lugar onde os limites históricos e as fronteiras geográficas se apresentam desprotegidas do sentido de propriedade por um grupo ou por grupos hegemônicos". Um trabalho artístico apolítico apenas na aparência, se concordarmos com a sugestão da epígrafe textual de Santigo, uma citação de Felix González-Torres: "Os mais bem sucedidos movimentos políticos são os que parecem não ser "políticos"”.

Este artigo investe principalmente na vontade de formular seu tema a partir de um gesto crítico análogo ao de Silviano Santiago. Gesto que se faz necessário devido a meu interesse muito particular ${ }^{2}$ em relação à obra do intelectual palestino e norteamericano Edward W. Said (1935-2003), a qual é fortemente marcada por seu engajamento político, sobretudo na questão da Palestina, e por sua inserção no contexto dos estudos pós-coloniais, como crítico literário e cultural. A mera citação do nome de Said já convoca a leitura formada sobre ele, situando-o em um determinado campo de problemas, que aponta para a discussão de questões principalmente político-culturais.

Entretanto, ao elaborar minha proposta de leitura de textos ensaísticos e narrativos de Said, enfatizo aspectos supostamente secundários em sua obra: os elementos autobiográficos relacionados à sua produção intelectual. $\mathrm{O}$ fato de me basear nessa ênfase, fomentando uma leitura que se distancia daquela mais usual, não se dá por uma necessidade de romper com a tradição interpretativa da obra de Said, e menos ainda por desmerecê-la. 
Poderia afirmar que meu interesse por questões tidas como marginais à obra de Said se aproxima daquilo que ele faz no último livro em que estava trabalhando quando faleceu, em setembro de 2003. Publicado postumamente, Estilo tardio se concentra em "grandes artistas que, no fim de suas vidas, criaram um novo idioma para sua obra e seu pensamento", e tem Beethoven como um de seus principais exemplos (Said, 2009, p. 26). Esse período tardio, à primeira vista não preponderante e de importância apenas acessória, é o tema escolhido por Said, quando ele mesmo enfrentava um câncer diagnosticado dez anos antes:

Qualquer um de nós poderia citar casos de obras tardias que coroam uma vida de trabalho estético. Rembrandt e Matisse, Bach e Wagner. Mas o que dizer de obras tardias que não são feitas de harmonia e resolução, mas de intransigência, dificuldade e contradição em aberto? [...] Gostaria de explorar a experiência de um estilo tardio que tem a ver com uma tensão despida de harmonia ou serenidade, com uma produtividade conscientemente improdutiva, do contra... (Said, 2009, p. 27).

Voltando às metáforas usadas por Silviano Santiago, com as quais comecei este artigo, também me deparo com um tipo de muro ao me debruçar sobre os elementos autobiográficos em textos ensaísticos e narrativos de Said. Pois, esse recorte, interessado em suas relações com as noções de "Oriente" e "oriental", acaba me levando à escolha de não travar um diálogo direto com a bibliografia já consolidada e instaurada em torno de seu nome e de certas temáticas pós-coloniais, como o seu engajamento político na causa palestina.

Meu diálogo será, sobretudo, com uma espécie de lacuna da crítica sobre Said, aquela relacionada ao tema das escritas de si e à suposta ruptura entre as culturas

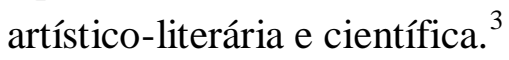

$\mathrm{Na}$ tentativa de dispor de um modo, ainda que provisório, de escapar aos temas que se impõem quando se trabalha com textos de Edward Said, penso que estou lidando não com uma muralha, mas com uma "murada", cujo sentido, primeiramente, imaginei ser o de um muro sutilmente mais baixo, que mais convida o olhar de curiosos do que limita a entrada de estranhos - talvez tenha sido só uma confusão minha com a palavra "mureta". De todo modo, e para minha surpresa, a acepção de "murada" adotada pelo dicionário Aurélio parece ser ainda mais promissora: "fiada de malhas em toda a largura da rede".

Diante dessa possibilidade, devemos aqui investir em termos menos familiares a um vocabulário relacionado à obra de Said, ainda que isso implique a constatação de que o viés de seu engajamento político se mostra, por sua abrangência, mais produtivo.

A meu ver, o gesto continuaria válido. Não há aqui planos de se escalar muros ou muralhas. Trata-se, apenas, de vislumbrar uma possibilidade de atravessamento, entre os espaços e cesuras na malha da rede. 


\section{2) Said entre os 'intelectuais hifenizados'}

Nos agradecimentos de $O$ local da cultura, o crítico indo-britânico Homi Bhabha (1998, p. 11) menciona a obra pioneira de Edward Said, que lhe forneceu "um terreno crítico e um projeto intelectual". Em seguida, ele cita os "níveis elevados de instigação" estabelecidos pela indiana Gayatri Spivak e a obra inspiradora do jamaicano Stuart Hall. Juntos, Said, Bhabha, Spivak e Hall estão entre os mais conhecidos "intelectuais hifenizados", cuja dupla ou múltipla inscrição cultural influenciou seus trabalhos teóricos e políticos, desenvolvidos em centros acadêmicos de destaque, a partir da segunda metade do século XX. ${ }^{4}$

Essa relação entre obra e experiência de vida, não mais entendida por uma mera lógica de causa e efeito, ganha novas possibilidades teóricas a partir das tendências atuais da crítica literária e (auto)biográfica. Em Crítica cult, Eneida Maria de Souza (2002, p. 110-111) aborda esse tema ao constatar que "a enunciação crítico-biográfica" dos teóricos filiados aos estudos culturais, bem como aos estudos literários e históricos, ${ }^{5}$ surge como resposta a análises anteriores que eram pautadas pela "objetividade e pelo distanciamento excessivo do sujeito da enunciação." De acordo com Souza, essa inserção do intelectual no texto por ele assinado reivindica o direito do sujeito de se posicionar diante do objeto, o que, ao mesmo tempo, "implica o papel contraditório do autor, ao reconhecer tanto a construção precária de si como sujeito quanto a necessidade de se assumir como cidadão" (Souza, 2002, p. 110).

O posicionamento do "eu" no discurso se dá nesse contexto em que velhas crenças são minadas, com cada vez mais forças, a ponto de se tornar insustentável o sujeito visto como "estereótipo da totalidade", capaz de compor um relato de vida considerado "registro de fidelidade e autocontrole" (Souza, 2002, p. 107). Assim, perscrutamos um terreno que não é mais o do sujeito pleno, dotado da capacidade de acessar a Verdade - tampouco o da objetividade sem qualquer intervenção de processos de singularização.

Para Félix Guattari, os processos de singularização seriam uma maneira de recusar a subjetividade tal como o indivíduo a recebe, "para construir modos de sensibilidade, modos de relação com o outro, modos de produção, modos de criatividade que produzam uma subjetividade singular". (Guattari; Rolnik, 2005, p. 2242). Assim, ele propõe que a apropriação dos componentes supostamente fixos da subjetividade faria parte de um processo de singularização.

Considero que o conflito de reconhecer tanto a construção precária de si como sujeito quanto a necessidade de se posicionar como cidadão - a partir de um processo de singularização - está presente de maneira contundente na obra de Edward Said. No contexto dos "intelectuais hifenizados", seu projeto se mostra radical quanto à articulação entre elementos autobiográficos e produção teórica, devido ao relevo dado à questão, na medida em que construiu sua imagem pública. 
Este é o autorretrato reforçado por Said: o de um intelectual em diálogo e tensão com seu lado "oriental" (ligado predominantemente à origem familiar e à infância) e seu lado "ocidental" (relacionado, com mais ênfase, à educação formal e à carreira profissional). Em alguma medida, a fusão entre "Oriente" e "Ocidente" representaria, em Said, a zona de indistinção entre as esferas privada e pública de sua vida.

Essas observações que assinalo sobre um projeto teórico-crítico que se construiu inseparavelmente de seus elementos autobiográficos são baseadas em meu percurso de leitura de Said, que apresentarei a seguir. Apesar da possível dimensão localizada desses comentários, eles oferecem um caminho para a problematização da ideia de "Oriente".

\section{3) Elementos autobiográficos em Said: um percurso de leitura}

Na introdução de Orientalismo: o Oriente como invenção do Ocidente (2007), lançado em 1978 e traduzido para mais de 35 idiomas, Said apresenta suas motivações pessoais para estudar o surgimento, o desenvolvimento e a consolidação do Orientalismo, a partir de textos históricos, políticos e ficcionais:

Muito do investimento pessoal neste estudo deriva da minha consciência de ser um 'oriental', por ter sido uma criança que cresceu em duas colônias britânicas. Toda a minha educação, naquelas colônias (Palestina e Egito) e nos Estados Unidos, foi ocidental, e ainda assim aquela primeira consciência profunda persistiu. De muitas maneiras, o meu estudo do Orientalismo foi uma tentativa de inventariar em mim o sujeito oriental, os traços da cultura cuja dominação tem sido um fator tão poderoso na vida de todos os orientais. É por isso que para mim o Oriente islâmico teve de ser o centro da atenção. [...] Ao longo do caminho, com toda a severidade e a racionalidade de que fui capaz, tentei manter uma consciência crítica, bem como empregar aqueles instrumentos de pesquisa histórica, humanística e cultural de que a minha educação me tornou o feliz beneficiário. Em nada disso, entretanto, jamais perdi a consciência da realidade cultural de um 'oriental', o envolvimento pessoal de ter sido constituído como um 'oriental'. (Said, 2007, p. 57. Grifo nosso).

Nesse trecho, Said dá a impressão de manter algum tipo de controle sobre as influências não-ocidentais que recebeu na infância, por ter consciência das marcas deixadas pela vivência da realidade cultural de alguém constituído como "oriental". Algo que retornaria, mais tarde, no estudo acadêmico motivado pela tentativa de fazer um "inventário" desse sujeito oriental. Em textos posteriores, ele menciona essas influências de maneira diferente, com mais ambiguidade e complexidade.

Mais de 15 anos depois, no posfácio à edição de Orientalismo publicada em 1995, Said responde às discussões levantadas por seu livro, avaliando as diversas interpretações que recebeu. Ele reforça que seu estudo só se tornou possível pelo fato de ter conseguido atravessar a "linha divisória imperial Leste-Oeste" e entrar na "vida do Ocidente", ao mesmo tempo em que conservou uma "conexão orgânica" com o lugar de origem: "Repetiria que foi muito mais um procedimento de cruzar barreiras do que de mantê-las; acredito que Orientalismo como livro o demonstre" (Said, 2007, p. 446-447). 
Nesse posfácio, ao mencionar a resenha de Basim Musallam como "uma das análises mais perspicazes e inteligentes" sobre seu livro, Said (2007, p. 447-448) cita o trecho a seguir, indicador da importância do elemento biográfico: "Não foi um 'árabe' qualquer que escreveu este livro, mas um árabe com uma formação e experiência particular".

Depois, seu tom fica mais expressivo ao se referir diretamente às acusações de ter dado um tratamento "talvez até sentimental" não apenas a Orientalismo, mas a suas obras em geral (Said, 2007, p. 451). Dessa maneira, ele defende com veemência seu posicionamento em relação aos temas que trabalha criticamente:

\begin{abstract}
Alegro-me que [todas as minhas obras] tenham recebido esses ataques! Orientalismo é um livro de quem toma partido, não é uma máquina teórica. [...] O que tentei preservar na minha análise do Orientalismo foi sua combinação de consistência $e$ inconsistência, seu jogo, por assim dizer, que só pode ser descrito preservando para quem o descreve, como escritor e crítico, o direito a algum ímpeto emocional, o direito de se comover, enfurecer, surpreender e deleitar. (Said, 2007, p. 451).
\end{abstract}

Como argumenta Eneida Maria de Souza, o reconhecimento do direito de se posicionar diante do objeto de estudo - incluo aí o direito "a algum ímpeto emocional" - tensiona-se com as dificuldades de se identificar uma composição possível desse sujeito. Ainda no posfácio da edição de 1995 de Orientalismo, Said (2007, p. 442) se inscreve nesse campo de discussão, ao falar da resistência que a maioria das pessoas tem à noção de que "a identidade humana não é natural e estável, mas construída e de vez em quando inteiramente inventada".

O processo de Said para construir sua própria imagem, frágil e complexa em muitos pontos, merece ser observado com atenção. Em 2003, ele assina um prefácio dedicado à edição daquele ano de Orientalismo: o Oriente como invenção do Ocidente. Nesse texto, afirma que o livro e sua obra intelectual foram possibilitados por sua vida de acadêmico universitário, especialmente em Columbia, nos Estados Unidos:

Jamais ensinei coisa alguma sobre o Oriente Médio, pois, por treinamento e prática, sou professor de humanidades, sobretudo as europeias e as americanas, e especialista em literatura comparada. A universidade e meu trabalho pedagógico com duas gerações de estudantes de primeira linha e excelentes colegas possibilitaram o tipo de estudo deliberadamente meditado e analítico presente neste livro, o qual, com toda a urgência de suas referências planetárias, continua sendo um livro sobre cultura, ideias, história e poder, mais do que sobre a política do Oriente Médio tout court. (Said, 2007, p. 12-13).

Nesse ponto, Said enfatiza sua atuação como professor, fundamental na constituição de seu processo de singularização. Já a consciência de ter se constituído como um oriental, mencionada na introdução de 1978, conforme comentei, é evocada nesse prefácio de forma mais nuançada, por meio da menção a sua autobiografia, intitulada Fora do lugar: memórias (2004). Expressões como "penso eu" dão mais 
espaço para suposições sobre as vivências da infância e da adolescência, impossíveis de serem totalmente elucidadas na vida adulta, e suas ligações com a obra teórica:

Como falei há muitos anos, Orientalismo é o produto de circunstâncias que são, fundamentalmente, ou melhor, radicalmente, fragmentos. Em meu livro de memórias, Fora do lugar [...], descrevi os mundos estranhos e contraditórios em que cresci, oferecendo a mim mesmo e a meus leitores um relato detalhado dos cenários que, penso eu, me formaram na Palestina, no Egito e no Líbano. Contudo, Fora do lugar era apenas um relato muito pessoal, que deixava de fora todos os anos de meu engajamento político, iniciado depois da guerra árabe-israelense de 1967 [...]. (Said, 2007, p. 12. Grifo nosso).

Esse relato "muito pessoal" da autobiografia de Said se destaca radicalmente em termos da ênfase de seu projeto teórico nas relações entre experiências de vida e produção intelectual, conforme sugiro. Contudo, é importante ressaltar que esse destaque não acontece devido a uma associação vida-obra óbvia ou explicativa - o que também acaba desfavorecendo possíveis interpretações mais lógicas e fechadas da trajetória de Said.

Sobretudo, o fato de Said não narrar a história de como se tornou uma voz destacada sobre os conflitos do Oriente Médio contraria o que seria de se esperar de um intelectual do século XX aproximando-se do fim da vida, altamente reconhecido por sua atuação política. Nesse contexto, os episódios da infância e da adolescência contados em Fora do lugar são aparentemente menores em comparação com os temas debatidos ao longo da carreira de Said. A frustação dessa expectativa é objeto de análise da teórica de literatura e cultura Heidrun Krieger Olinto, no artigo "Memórias e histórias pessoais" (2006).

Olinto considera (2006, p. 127-128) curioso o livro de memórias de Edward Said, segundo ela, "um dos intelectuais contemporâneos mais respeitados", "representante da esquerda pós-estruturalista nos Estados Unidos, que não só levantava a bandeira do ativismo político no espaço da academia, mas durante décadas, se envolvia diretamente na causa palestina":

Deslocando o acento sobre doces e amargas memórias íntimas da vida do jovem Said em busca de identidade, ele explora o sentimento de estar fora do lugar antes no contexto cultural e familiar que, no entanto, revela as raízes do seu deslocamento simultaneamente intelectual, político e pessoal. Mesmo assim, Fora do lugar apenas marginalmente pode ser considerado um livro político que descreve a trajetória de uma vida particular marcada pelo acento sobre o engajamento político. (Olinto, 2006, p. 128).

A meu ver, como Said se detém em situações sensivelmente pessoais, deixando de fora os anos de engajamento político, isso facilita o desenho e redesenho dos laços entre vida e obra por parte do leitor, por esquemas menos convencionais. Ao mesmo tempo em que disponibiliza mais material (auto)biográfico para análise crítica, afasta conexões sólidas e inquestionáveis com a figura do intelectual Edward Said. 
De qualquer maneira, Fora do lugar segue algumas convenções internas a seu modelo narrativo: por exemplo, a ênfase em um relato focado na juventude, enquanto o presente seria o momento distanciado da escrita, é percebida ao longo do texto especialmente pelo uso de expressões temporais como "agora, ao escrever isso" e "exatamente cinquenta anos depois" (Said, 2004, p. 106 e p. 74). Considero que se trata de uma diferenciação entre as instâncias do narrador Said e do personagem Said - o que, de certa forma, tenta conferir veracidade à narrativa pessoal sobre o passado.

No prefácio de sua autobiografia, há uma mostra do jogo narrativo operado por Said, envolvendo os diversos papéis que desempenha como autor, narrador e personagem. O narrador afirma, logo na primeira frase, que "Fora do lugar é um registro de um mundo essencialmente perdido ou esquecido" (Said, 2004, p. 11). No último parágrafo, diz que a principal razão de suas "memórias" é "a necessidade de atravessar a distância de tempo e espaço" entre sua vida atual e sua vida de então, tendo como resultado "um certo distanciamento irônico na postura e no tom quanto à reconstrução de uma época e de uma experiência remotas" (Said, 2004, p. 16. Grifo nosso). Contudo, encerra esse preâmbulo com a garantia de que poderá ser honesto a respeito de suas "lembranças, experiências e sentimentos", assumindo o papel de narrador implacável de si mesmo como personagem:

\begin{abstract}
Várias pessoas descritas aqui ainda estão vivas e provavelmente discordarão ou ficarão descontentes com o retrato que faço delas e dos outros. Por menos que eu quisesse ferir quem quer que fosse, minha primeira obrigação não era ser simpático, mas sim honesto com minhas talvez peculiares lembranças, experiências e sentimentos. Eu, e somente eu, sou responsável pelo que recordo e vejo, não indivíduos do passado que não poderiam saber que efeito tiveram sobre mim. Espero que fique claro também que, tanto na qualidade de narrador quanto na de personagem, resolvi conscientemente não poupar a mim mesmo das mesmas ironias ou revelações embaraçosas. (Said, 2004, p. 16).
\end{abstract}

Esse jogo narrativo também está atrelado às alternâncias de referências a si mesmo em primeira e terceira pessoas do singular. Said chega a se referir a "Edward", usando as aspas: "'Edward' era principalmente o filho, em seguida o irmão e finalmente o menino que tentava em vão seguir (ou ignorar e contornar) todas as regras. [...] Poderia a posição de 'Edward' ser outra senão fora do lugar?” (Said, 2004, p. 42).

Esboçado na moldura desse autorretrato, o personagem que sobressai é um estrangeiro fora de lugar na própria família e em qualquer parte do mundo, permeado pelas ambivalências do deslocamento. Considero que se trata de um personagem que não corresponde à ideia tradicional de sujeito, devido ao questionamento de Said à noção de identidade estável:

Às vezes me sinto como um feixe de correntes que fluem. Prefiro isso à ideia de um eu sólido, à identidade a que tanta gente dá importância. [...] Com tantas dissonâncias em minha vida, de fato aprendi a preferir estar fora do lugar e não absolutamente certo. (Said, 2004, p. 429). 
Como o título do livro já faz alusão, a sensação de não pertencimento é constante e se apresenta de diferentes modos, como o desconforto em ter que conciliar, conforme Said (2004, p. 19) narra, "um nome ridiculamente inglês" e o "sobrenome inequivocamente árabe" - uma combinação que provocava situações embaraçosas:

Durante anos, dependendo das circunstâncias específicas, eu pronunciava rapidamente o 'Edward' e enfatizava o 'Said'; em outras ocasiões, fazia o contrário, ou então juntava um nome no outro de modo tão rápido que nenhum dos dois soava claro. A única coisa que eu não podia tolerar, mas que muitas vezes fui obrigado a sofrer, era a reação descrente e, por conta disso, desalentadora: Edward? Said? (Said, 2004, p. 20).

Essa questão do nome próprio se vincula ainda ao que ele chama de "cisão básica" de sua vida: o fato de não saber que língua era realmente a sua, se o árabe ou o inglês (Said, 2004, p. 14). No artigo "Entre mundos", de Reflexões sobre o exílio e outros ensaios, Said (2003, p. 304) comenta os intercâmbios existentes nessa cisão, entre o árabe como "língua materna" e o inglês como "idioma escolar": "nunca soube qual era a minha primeira língua e nunca me senti plenamente à vontade nas duas, embora sonhe em ambas. Toda vez que pronuncio uma frase em inglês, ouço seu eco em árabe, e vice-versa". ${ }^{6}$

Assim, grande parte de Fora do lugar é dedicada a uma espécie de acerto de contas com os pais e, consequentemente, com as experiências no mundo árabe. Várias páginas tratam da relação conflituosa com o pai, cuja história antes de se tornar chefe de família parece obscura e fragmentada - inclusive em relação aos acontecimentos que o levaram a participar da Primeira Guerra Mundial servindo ao Exército americano, o que lhe valeu a cidadania norte-americana, estendida a seus filhos, mas não a sua esposa. $\mathrm{O}$ relato de Said destaca especialmente o sentimento de inferioridade em relação ao pai, um chefe de família tradicional e empresário ousado e bem-sucedido.

Quaisquer que tenham sido os fatos históricos reais, meu pai representou uma combinação devastadora de poder e autoridade, disciplina racionalista e emoções reprimidas; e tudo isso, como percebi depois, influenciou minha vida inteira, com alguns efeitos bons, mas com outros inibidores e debilitantes. À medida que fui crescendo, encontrei o equilíbrio entre esses efeitos, mas de minha infância até os vinte e poucos anos fui muito controlado por ele. (Said, 2004, p. 31-32).

A relação com a mãe é descrita com mais afeto e intimidade, mas, ainda assim, contendo altas doses de ambiguidade. Companheira mais próxima ao menos até Said completar 25 anos, a mãe era dona de casa e compartilhava com o ele a paixão pela música e pela leitura. Também cobrava, com vigor, amor e devoção do único filho homem: "[Minha mãe] dava-os de volta dobrados e redobrados; mas ela também podia afastá-los de repente, produzindo em mim um pânico metafísico que ainda sou capaz de experimentar com considerável desagrado e mesmo terror" (Said, 2004, p. 32-33).

As memórias de Said visitam ainda experiências e sentimentos confusos envolvendo seu amadurecimento sexual, a relação reprimida com o próprio corpo e com 
as mulheres na juventude, o relacionamento distante e competitivo com as irmãs, a música e a literatura como uma abertura possível para o mundo das sensibilidades. Nesse cenário de sensações, também expõem episódios em que sofreu forte humilhação, que reforçam a inadequação de Said a seu ambiente familiar e social.

Um deles ocorre quando o pai impõe uma punição física, de maneira devastadora para o personagem Said:

\begin{abstract}
Ele sabia ser fisicamente violento e me dava tapas sonoros no rosto e no pescoço, enquanto eu me encolhia e me esquivava de um modo que me parecia dos mais vergonhosos. Eu lastimava indizivelmente sua força e minha fraqueza, mas nunca respondi ou protestei, nem mesmo quando, como estudante de graduação em Harvard, aos vinte e poucos anos, fui surrado por ele de forma humilhante, por ter, segundo ele, sido rude com minha mãe. (Said, 2004, p. 105-106).
\end{abstract}

Outra cena de humilhação pela agressão física acontece quando era mais novo e ainda estudava no Victoria College, no Cairo. Flagrado jogando pedras durante um intervalo, ele é punido com seis golpes de vara de bambu por um funcionário, a mando do diretor da escola britânica, da qual é expulso meses depois. "Vivi a coisa como algo que se deveria esperar numa situação de guerra", afirma o narrador (Said, 2004, p. 275 277), para quem o diretor da instituição, sr. J. G. E. Price, uma "floresta de iniciais", era a própria "encarnação da autoridade colonial em declínio".

No artigo já mencionado de Reflexões sobre o exílio e outros ensaios, a ideia de guerra também é usada no trecho em que Said (2003, p. 305) comenta outro aspecto de sua formação familiar: o fato de ter sido batizado na Igreja Anglicana. Segundo ele, os hinos belicosos cantados nas missas, entoando frases como "Adiante, soldados cristãos" e "Das montanhas geladas da Groenlândia", deixavam-no em uma situação ainda mais complicada: encenar ao mesmo tempo o papel de agressor e agredido, em um "estado de permanente guerra civil".

Nesse texto, Said (2003, p. 315) afirma ainda que os três lugares onde cresceu deixaram de existir, tanto a Palestina quanto o Egito colonial e monárquico e também o Líbano anterior aos 20 anos de guerra civil. No entanto, a construção de sua figura pública consegue tornar visível esse desaparecimento, pois é influenciada, inevitavelmente, pela necessidade de expressar para uma "plateia ocidental" certos aspectos silenciados do mundo oriental:

Em Orientalismo e em Cultura e imperialismo, e depois nos cinco ou seis livros explicitamente políticos sobre a Palestina e o mundo islâmico que escrevi na mesma época, senti que estava moldando um eu que revelava para a plateia ocidental coisas que até então estavam escondidas ou não haviam sido discutidas. Assim, ao falar sobre o Oriente, que até aquele momento se acreditava ser um simples fato da natureza, tentei desvelar a obsessão geográfica antiga e muito variada por um mundo distante, amiúde inacessível, que ajudou a Europa a se definir como o oposto. (Said, 2003, p. 312-313. Grifo nosso). 
Neste ponto, gostaria de apresentar minha leitura desse personagem estrangeiro "fora do lugar" incorporado e encenado por Said. Como sugeri no começo deste artigo, procuro por trilhas, pequenos espaços, que pudessem dar um novo giro, uma nova articulação ao saber produzido por esse intelectual.

Sigo em busca desse gesto.

\section{4) Saber e sabor}

Para elaborar minha proposta de leitura dos elementos autobiográficos em Edward Said, inspiro-me no pensamento do intelectual francês Roland Barthes. Mais especificamente, no livro Aula (2007), que traz a transcrição da aula inaugural de Barthes no Collège de France. ${ }^{7}$ Em janeiro de 1977, ao assumir a cadeira de Semiologia Literária, ele precisou cumprir essa formalidade acadêmica, que exige a descrição da formação e do percurso teórico-intelectual.

Sua apresentação, entretanto, é pelos desvios de um "sujeito incerto"; ou seja, incita antes a "aventura de certo sujeito" do que a consagração da disciplina Semiologia (Barthes, 2007). Nessa Aula, ele pensa a escritura ${ }^{8}$ como uma possibilidade de criação de um saber dramático, que encena a linguagem: "através da escritura, o saber reflete sobre o saber, segundo um discurso que não é mais epistemológico, mas dramático" (Barthes, 2007, p. 19).

Nessa perspectiva, a velha oposição entre ciência e literatura (termo intercambiável, nesse contexto, com a ideia de escritura) só continuaria pertinente para evidenciar lugares diferentes de fala, para assinalar um uso específico da linguagem, não técnico, em que o saber se encena.

Para explicitar melhor essa reflexão, recorto um trecho mais longo da aula, pois nele é sugerida uma articulação interessante entre escritura, enunciação do sujeito e construção de saber:

Segundo o discurso da ciência - ou segundo certo discurso da ciência - o saber é um enunciado; na escritura, ele é uma enunciação. O enunciado, objeto habitual da linguística, é dado como o produto de uma ausência do enunciador. A enunciação, por sua vez, expondo o lugar e a energia do sujeito, quiçá sua falta (que não é sua ausência), visa o próprio real da linguagem; ela reconhece que a língua é um imenso halo de implicações, de efeitos, de repercussões, de voltas, de rodeios, de redentes; ela assume o fazer ouvir um sujeito ao mesmo tempo insistente e insituável, desconhecido e no entanto reconhecido segundo uma inquietante familiaridade: as palavras não são mais concebidas ilusoriamente como simples instrumentos, são lançadas como projeções, explosões, vibrações, maquinarias, sabores: a escritura faz do saber uma festa. (Barthes, 2007, p. 19-20. Grifos nossos).

Esse sujeito da enunciação (um processo em constante funcionamento, que não se encerra), insistente e insituável a um só tempo, remete ao papel contraditório do teórico que associa a constituição precária de si mesmo como sujeito e a necessidade de se posicionar no discurso, de que falara Eneida Maria de Souza. Sujeito insistente e 
insituável que parece percorrer escritos de Edward Said, frequentemente alternando seu pensamento e sua biografia.

Eneida Maria de Souza também se interessa pela dramatização do saber em Tempo de pós-crítica, texto originalmente apresentado como "Memorial" de concurso para professor titular de Teoria da Literatura da UFMG. Ela elege a escrita ensaística como a forma mais propícia para a "encenação de histórias e a dramatização dos enunciados", que revitalizam a dimensão provisória do relato de experiência, desviandose do "caráter demonstrativo e fechado dos tratados" (Souza, 2007, p. 20). Seria uma maneira de atravessar um espaço intermediário entre a teoria e a ficção, de se envolver nas malhas da enunciação e se ficcionalizar.

Nesse sentido, para Souza (2007, p. 21-22), um modo de flexibilizar ainda mais a fronteira entre ensaio e ficção é acentuar o aspecto espetacular da escrita, por meio da "apropriação da metáfora teatral na caracterização do sujeito como ator no discurso". Aqui, a ensaísta mineira convida Barthes para o diálogo:

Este [Barthes], ao privilegiar o saber da escritura como enunciação, coloca-o em desacerto com o saber da ciência [...]. O saber dramático - o texto, a escritura - suplanta o epistemológico, ao operar, segundo Barthes nos interstícios da ciência e promover a encenação das subjetividades. (Souza, 2007, p. 22).

Quero ainda acompanhar sem pressa o pensamento de Souza, ao menos por mais um parágrafo deste "Memorial" de um percurso intelectual, em que ela ensaia sua própria encenação de escrita de si:

O sujeito, em suas múltiplas feições, personagem que salta nas primeiras páginas deste texto da memória, ensaia uma escrita individual e esboça identidades. No momento em que se esforça para inscrever-se no território neutro da linguagem, reluta entre a indiscrição e a timidez, sobressaindo ou apagando-se nas entrelinhas de tantos nomes próprios e assinaturas. Investiga o papel ambivalente - sombra ora distante, ora próxima que desempenha na escrita, no instante em que reconstrói o seu/meu curriculum vitae e se lança à dramatização do enunciado que profere. (Souza, 2007, p. 19).

Lançar-se à dramatização de si: seria essa uma das mais potentes possibilidades de enunciação do frágil "eu" nos nossos tempos?

Precário sujeito, cuja legitimidade foi esfacelada diante de um indivíduo que não é mais único e autoidêntico - duas das suposições que se tornaram insustentáveis frente às novas exigências estabelecidas pelo pensamento crítico, segundo afirma Elizabeth Muylaert Duque-Estrada (2009, p. 21), na tese de doutorado em que estuda a atualidade da escrita de si. Ao sondar a nova situação da narrativa autobiográfica, ela constata um estilhaçamento do "auto", cuja melhor expressão poderia aparecer em uma frase de Candance Lang: "a autobiografia está em toda a parte ${ }^{9}$ onde se queira encontrá-la". Para Duque-Estrada (2009, p. 27), essa é "uma afirmação dramática" ${ }^{10}$ que parece suspender a autobiografia entre a sua possibilidade e impossibilidade". 
Neste momento, quero me sentar confortavelmente para assistir - mais uma vez, sem pressa - a um trecho específico da aula inaugural, pois é nele que vejo uma incrível potência lampejando, reluzindo nas ideias sugeridas por Barthes. Ao afirmar que o saber criado pela escritura, esse saber dramático, promove uma festa, de explosões, maquinarias e sabores, o professor acrescenta que também a escritura ${ }^{11}$ é encontrada "em toda parte onde as palavras têm sabor":

O paradigma que aqui proponho não segue a partilha das funções; não visa a colocar de um lado os cientistas, os pesquisadores, e de outro os escritores, os ensaístas; ele sugere, pelo contrário, que a escritura se encontra em toda parte onde as palavras têm sabor (saber e sabor têm, em latim, a mesma etimologia). (Barthes, 2007, p. 20).

Assim, o saber encenado pela escritura não está contido apenas em si mesmo. Esse saber pode atravessar discursos amorosamente, indistintamente - afinal, a velha distinção entre ciência e literatura tem pouquíssimas utilidades hoje em dia. Em Como viver junto, um dos cursos oferecidos no Collège de France, Barthes resume a aula inaugural como uma tentativa de postular "a possibilidade de ligar a pesquisa ao imaginário do pesquisador" (Barthes, 2003a, p. 329).

Liberdade de circulação do sabor, do saber: contestação de fronteiras, de categorias, de gêneros. Festa. Como quem diz de repente: "vou te fazer uma festa". E precipita a mão para bagunçar os cabelos do outro, desarrumá-los, num afago afetuoso, um tanto inesperado e desorganizado.

É em meio a movimentos como esses que eu gostaria de olhar positivamente para a escrita de si de Said: assistir ao personagem "fora do lugar" de seus textos ensaísticos e narrativos como uma forma afetuosa de acentuar o sabor da escrita e da produção de saber. Em outras palavras: vislumbro nesse personagem a aproximação entre sabor e saber já sugerida por Barthes.

Afinal, trata-se de um jogo de encenações que aguça o paladar para as texturas e os contrastes da escritura. Para falhas, fissuras, granulações, nós. O olhar repara, então, as questões não resolvidas, as margens deixadas pela escritura para se ensaiar novas ideias, sem a necessidade de se fixar identidades ou verdades definitivas.

Neste caso, anular o aspecto do sabor da escritura levaria a um saber construído como uma espécie de massa pasteurizada, homogênea, por só trabalhar com verdades prontas, com o que já se tornou a versão oficial do discurso. Uma massa discursiva tão absolutamente coerente que se torna insípida.

Portanto, aposto na estratégia discursiva de Said como uma maneira alternativa de construir conhecimento, sobretudo a partir da encenação de si na escrita - um saber dramatizado, não oficial, cujas texturas podem provocar os sentidos do leitor e, assim, iluminar as falhas e sobreposições do tecido do discurso autorizado e de suas afirmações supostamente objetivas. O personagem saboroso revela a construção histórica, cultural e política da ideia de "Oriente", por meio de seus fragmentos de memória, que falam de 
experiências de vida apagadas pela noção tradicional do "oriental" como alguém totalmente apartado do "Ocidente".

Nesse sentido, os elementos autobiográficos são empregados, especialmente, para rasurar ideias e discursos que até então tinham um caráter definitivo, acrescentando-se sabor à produção de saberes. A partir dessa perspectiva, o tom íntimo de Fora de lugar ganha novas nuances, ao dar mais vida à encenação de si, trazendo relatos que animam o personagem, ao mesmo tempo localizando-o na história de uma família e mostrando sua inadequação a esse ambiente estabelecido principalmente pelo pai. Narrativas que animam ainda cenários habitados no passado e que hoje parecem ter desaparecido para sempre: a Palestina, o Cairo, o Líbano da juventude de Said.

No ensaio "Entre mundos", que já citei aqui, Said comenta a época em que teria começado a se transformar em "uma pessoa totalmente ocidental". Segundo ele, esse momento teria ocorrido quando estudava nos Estados Unidos e visitava o Oriente Médio somente nas férias: "Na faculdade e na pós-graduação, estudei literatura, música e filosofia, mas nada disso tinha relação com minha própria tradição" (Said, 2003, p. 306). Ele descreve da seguinte maneira sua chegada como professor a Columbia, uma das principais universidades de Nova York, no outono de 1963:

[...] era visto como alguém que tinha um passado árabe exótico, mas irrelevante; com efeito, lembro que a maioria de meus amigos e colegas não usava a palavra 'árabe', muito menos 'palestino' para se referir a mim, preferindo o mais fácil e vago 'do Oriente Médio', termo que não ofendia ninguém. Um amigo que já lecionava em Columbia me contou mais tarde que, quando fui contratado, me descreveram no departamento como sendo um judeu de Alexandria! (Said, 2003, p. 307).

Mais adiante, ele relata uma mudança que teria realizado após perceber que tinha se forçado a aceitar um princípio de anulação da vida passada dos emigrados, devido às exigências do processo de adaptação ao "melting pot norte-americano":

Depois de assumir gradualmente o tom profissional de um professor universitário americano como maneira de submergir meu passado difícil e inassimilável, comecei a pensar e escrever de modo contrapontístico, usando as metades díspares da minha experiência, de árabe e americano, para trabalhar com ambas, e ao mesmo tempo, uma contra a outra. (Said, 2003, p. 309).

Em mais um ensaio, intitulado "Lembranças do Cairo: crescendo nas contracorrentes culturais dos anos 40 no Egito" (2003), Said escreve sobre a amizade com o pianista polonês Ignace Tiegerman, que foi seu professor no Cairo. No final da década de 1950, os dois compartilharam a admiração por uma das mais talentosas alunas de Tiegerman: uma mulher casada, com quatro filhos, que tocava piano com a cabeça toda coberta pelo véu da religião muçulmana. 
Nem ele nem eu conseguíamos entender aquela mulher anfíbia, que com uma parte de seu corpo era capaz de arrojar-se ao longo da Appassionata e, com a outra, com a face oculta, venerar Deus. [...] Tal como Tiegerman, ela era uma emanação intransplantável do espírito do Cairo, mas, ao contrário dele, seu ramo particular da história da cidade perdurara e até triunfara. Por um breve momento, então, a conjunção de culturas ultraeuropeia e ultra-islâmica produziu uma imagem que tipificava o Cairo de minha infância. Para onde imagens como essa foram desde então, eu não sei, mas parte de sua pungência para mim é que tenho certeza de que jamais voltarão. (Said, 2003, p. 107).

A pungência de certas imagens surge imediatamente em After the last sky (1999), realizado por Said em parceria com o fotógrafo suíço de origem alemã Jean Mohr. De acordo com Said (1999, p. 4-6), o livro foi uma tentativa de falar algo ainda não dito sobre os palestinos, entremeando textos seus e fotografias de Mohr, de maneira a expressar com mais complexidade a experiência daqueles que perderam a Palestina.

Para o intelectual palestino-americano, o apagamento dessas histórias passa não pelo silêncio total, mas exatamente pelo peso do excesso de discursos sobre os palestinos, pela "muralha" erguida por um imenso corpo de textos definindo a questão palestina:

At this point, no one writing about Palestine - and indeed, no one going to the Palestine starts from scratch: We have all been there before, whether by reading about it, experiencing its millennial presence and power, or actually living there for periods of time. It is a terribly crowded place, almost too crowded for what it is asked to bear by way of history or interpretation of history. Yet, for all the writing about them, Palestinians remain virtually unknown. (Said, 1999, p. 4).

Assim, After the last sky procura maneiras de tratar de vivências e histórias de pessoas sufocadas pelo que já se estabeleceu sobre a questão política da Palestina. A voz e as lembranças pessoais de Said permeiam as fotografias tiradas por Mohr, criando um espaço em que as imagens instigam a escrita de diversos fragmentos autobiográficos.

Uma delas mostra três adultos e uma criança vistas ao longe em Ramallah, em meio a casas cercadas por árvores e com terraços em patamares, ligados por várias escadas. Para Said (1999, p. 47), essa fotografia é uma evocação quase proustiana da Palestina:

Intimate memory and contemporary social reality seem connected by the little passage between the child, absorbed in his private, silent sphere, and the three older people, who are in the public world of adults, work and community [...]. All the force in the photograph moves dramatically from trees left to trees right, from the visible enclave of domesticity (stairs, house, terrace) to the unseen larger world of power and authority beyond. (Said, 1999, p. 48-49). 
O Oriente de Said, que se insinua em sua escrita-encenação de si, é o de afirmação dos limites da capacidade de imaginação do pensamento ocidental. Afirmação de experiências que existem e existiram para além das concepções que formam oficialmente o conhecimento sobre o Oriente. Vozes e vidas ameaçadas de se evaporar sem reconhecimento, mas que ganham fôlego no interstício entre literatura e ciência, no saber dramático encenado pela escritura.

No livro Contra a interpretação, Susan Sontag (1987, p. 338) discute o que considera uma suposta ruptura entre "duas culturas", a artístico-literária e a científica. “O conflito entre 'as duas culturas' é, na realidade, uma ilusão, um fenômeno temporário surgido em um período de profundas e desconcertantes mudanças históricas [a partir do século XVIII, com a Revolução Industrial]”, afirma (Sontag, 1987, p. 341. Grifo nosso). A partir dessa ideia de conflito ilusório entre duas culturas, sugiro que os elementos autobiográficos na produção intelectual de Said sejam lidos como uma maneira de se contestar as fronteiras entre afeto e teoria; ou seja, entre sensibilidades e afeto, geralmente mais associados à cultura "artístico-literária", e razão e teoria, mais relacionados pelo senso-comum à cultura "científica".

$\mathrm{E}$, com isso, num momento de lampejo, vozes e vidas encenadas na escritura nos acenam com a possibilidade de delinear um tipo de sensibilidade em que afeto e teoria se combinam e se confundem.

${ }^{1}$ Este artigo apresenta trechos de minha dissertação de mestrado, intitulada Said $e$ Barthes: Orientes possíveis nas escritas de si, defendida em março de 2013.

${ }^{2}$ Posso afirmar que esse interesse particular foi um desdobramento de um interesse inicial mais geral pela obra de Said, que desenvolvi em minha monografia de especialização em Literatura, Arte e Pensamento Contemporâneo, intitulada $O$ intelectual sem Pátria: desconstrução da nação na escrita de Edward W. Said. Cf. Aibe (2011).

${ }^{3}$ Tomo emprestados esses termos da discussão levantada por Susan Sontag no livro Contra a interpretação (1987), conforme abordarei no decorrer deste artigo.

${ }^{4}$ Uma questão marcante nesse contexto é a noção de "intelectual exilado", que abordei em minha monografia de especialização, sobretudo no capítulo "Said e a experiência do intelectual exilado", sobre as alternativas vislumbradas por Said para o intelectual que se posiciona na condição de exilado, principalmente a de não se submeter a uma fonte de poder como a nação. Cf. Aibe (2011).

${ }^{5}$ Um exemplo disso é a coletânea Ensaios de ego-história, publicada em 1987 pelo historiador francês Pierre Nora. Como explica Heidrun Krieger Olinto (2006, p. 130), Nora recolheu "'autobiografias intelectuais' de sete historiadores da chamada "nouvelle histoire" (entre os muitos chamados que declinaram do convite), que, dispostos a correr o risco de assumir expressamente a primeira pessoa do singular, expõem aspectos de sua vida privada, tentando vinculá-los com a sua experiência profissional e acadêmicoinstitucional em diversas fases de sua existência".

6 A propósito, alguns artigos selecionados em Reflexões sobre o exílio, publicados originalmente nas décadas de 80 e 90, já relatam experiências que aparecem em Fora do lugar. Mais adiante, tratarei deste tópico. 
${ }^{7}$ O professor do Collège de France, titular da Cadeira de Semiologia Literária, poderia ser considerado alguma forma de esboço de um "Barthes tardio", que ministrou seminários como O neutro (2003b) e A preparação do romance (2005a, 2005b). As anotações de aulas foram organizadas e publicadas depois de sua morte - uma morte "dramática", após ser atropelado na Rue des Écoles, em frente à universidade, em março de 1980.

${ }^{8}$ No original, Barthes fala em écriture. A tradução do termo para o português gera polêmicas, devido à possibilidade de escolha entre "escrita" ou "escritura". No trecho a seguir, Leyla Perrone-Moisés (2007, p. 78) explica por que traduziu a palavra por "escritura": "Digamos apenas que, para Barthes, a escritura é a escrita do escritor. Nesta Aula, ele propõe o uso indiferenciado de literatura, escritura ou texto, para designar todo discurso em que as palavras não são usadas como instrumentos, mas postas em evidência (encenadas, teatralizadas) como significante".

${ }^{9}$ É importante grifar essa expressão para a discussão que interessa a este artigo.

${ }^{10}$ Grifo nosso.

${ }^{11} \mathrm{Ou}$ a literatura, pois, como já vimos, nesse espaço da "aula inaugural" é possível afirmar que tanto faz dizer um ou outro.

\section{Referências bibliográficas}

AIBE, Mayumi Senra. O intelectual sem Pátria: desconstrução da nação na escrita de Edward W16. Said. Rio de Janeiro, 2011. 28p. Monografia (Especialização em Literatura, Arte e Pensamento Contemporâneo) - Departamento de Letras, PUC-Rio.

BARTHES, Roland. Aula: aula inaugural da cadeira de semiologia literária do Colégio de França, pronunciada dia 7 de janeiro de 1977. Tradução de Leyla Perrone-Moisés. São Paulo: Cultrix, 2007.

A preparação do romance I: da vida à obra. Tradução de Leyla Perrone-Moisés. São Paulo: Martins Fontes, 2005a.

A preparação do romance II: a obra como vontade: notas de curso no Collège de France 1979-1980. Tradução de Leyla Perrone-Moisés. São Paulo: Martins Fontes, 2005b.

Como viver junto: simulações romanescas de alguns espaços cotidianos: cursos e seminários no Collège de France, 1976-1977. Tradução de Leyla Perrone-Moisés. São Paulo: Martins Fontes, 2003a.

O neutro: anotações de aulas e seminários no Collège de France, 1977-1978. Tradução de Ivone Castilho Benedetti. São Paulo: Martins Fontes, 2003b.

BHABHA, Homi K. O local da cultura. Tradução de Myriam Ávila, Eliana Lourenço de Lima Reis, Gláucia Renate Gonçalves. Belo Horizonte: Editora UFMG, 1998. 
BORGES, Jorge Luis. Pierre Menard, Autor do Quixote. In: . Ficções. Tradução de Carlos Nejar. São Paulo: Editora Globo, 1989, p. 29-38.

DUQUE-ESTRADA, Elizabeth Muylaert. Devires autobiográficos: a atualidade da escrita de si. Rio de Janeiro: NAU Editora; Editora PUC-Rio, 2009.

GUATTARI, Félix. ROLNIK, Suely. Micropolítica: cartografias do desejo. Petrópolis: Vozes, 2005.

NORA, Pierre. Ensaios de ego-história. Tradução de Ana Cristina Cunha. Lisboa: Edições 70, 1989.

OLINTO, Heidrun Krieger. Memórias e histórias pessoais. In: SCHØLLHAMMER, Karl Erik (Org.). Literatura e Memória. Rio de Janeiro: Edições Galo Branco, 2006, p. 125-136.

PERRONE-MOISÉS, Leyla. Lição de casa. In: BARTHES, Roland. Aula: aula inaugural da cadeira de semiologia literária do Colégio de França, pronunciada dia 7 de janeiro de 1977. São Paulo: Cultrix, 2007, p. 47-95.

SAID, Edward W. Estilo tardio. Tradução de Samuel Titan Jr. São Paulo: Companhia das Letras, 2009.

Orientalismo: o Oriente como invenção do Ocidente. Tradução de Rosaura Eichenberg. São Paulo: Companhia das Letras, 2007.

Fora do lugar: memórias. Tradução de José Geraldo Couto. São Paulo: Companhia das Letras, 2004.

Reflexões sobre o exílio e outros ensaios. Tradução de Pedro Maia Soares. São Paulo: Companhia das Letras, 2003.

After the last sky: Palestinian lives. Photographs by Jean Mohr. New York: Columbia University Press, 1999.

SANTIAGO, Silviano. O começo do fim. Revista Gragoatá, Niterói, n. 24, p. 13-30, 1. sem. 2008.

Eça, autor de Madame Bovary. In:

Literatura nos

trópicos: ensaios sobre dependência cultural. Rio de Janeiro: Rocco, 2000, p. 47-65.

SONTAG, Susan. Uma cultura e a nova sensibilidade. In: Contra a interpretação. Tradução de Ana Maria Capovilla. Porto Alegre: L\&PM, 1987.

SOUZA, Eneida Maria de. Tempo de pós-crítica: ensaios. São Paulo: Linear B; Belo Horizonte: Veredas \& Cenários, 2007. 
Notas sobre crítica biográfica. In: Horizonte: Editora UFMG, 2002, p. 105-113.

. Crítica cult. Belo 